\title{
28. Sanatkârların mizaç ve kişiliklerinin eserlerine yansıması üzerine bir çalışma*
}

\section{Mehrali CALP}

APA: Calp, M. (2021). Sanatkârların mizaç ve kişiliklerinin eserlerine yansıması üzerine bir çalışma. RumeliDE Dil ve Edebiyat Araştırmaları Dergisi, (24), 531-547. DOI: 10.2900o/rumelide.990132.

$\ddot{O} \mathbf{z}$

Edebî eser ile okur, tarih ve toplum arasında ilişki kurulabileceği gibi sanat eseri ile sanatkârın mizacı arasında da ilişki kurulabilir. Edebî eserlerin, sanatkârlarının duygu ve düşüncelerini yansıttığını ileri süren eleştiri yöntemlerinin varlı̆̆ı bu görüşü desteklemektedir. Bu görüşe göre, sanat, duyguların ifadesidir ve onu üreten yazarın kişiliğini yansıtır. Bu araştırmanın amacı, sanat ile mizaç arasındaki ilişki bağlamında Türk edebiyatının ünlü şairlerinden Ahmet Haşim, Behçet Necatigil ve Necip Fazıl'ın birer şiirinden hareketle mizaç farklılaşmasını incelemek ve örneklendirmektir. Bu kapsamda, her biri kendine özgü sanat anlayışına sahip bu üç sanatkârın birer eseri ele alınmış ve bu eserlere yansıyan mizaçları okur bakış açısından yorumlanmıştır. Doküman incelemesi yöntemi kullanılmıştır. Elde edilen bulgular ışı̆̆ında, her sanatkârın farklı bakış açısına sahip olduğu, eserlerini üretirken her birinin kendi mizaçlarının etkisinde kaldı̆̆ı, eserlerinde görünen ve görünmeyen nesneleri farklı yansıttığı gözlenmiştir. Örneklem olarak alınan şiirlerde, Ahmet Hâşim'in biyolojik varlığı olan başıyla uyumsuzluğu ve buna bağlı olarak kendini horlayışı, Behçet Necatigil'in insanların nobran tutum ve davranışlarına, toplumdaki sosyo-ekonomik adaletsizliklere tepkili oluşu; Necip Fazıl'ın iç dünyasının dış dünyadaki kurulu düzenle uyuşmaması öne çıkan temlerdir. Sonuç olarak gerek mizaçlarının gerekse eserlerinin özgün olmasıyla Türk Edebiyatında seçkin bir yer elde etmiş bu sanatkârların ortak yönleri, içinde bulundukları dış dünyaya karşı, farklı ve özgün tepkide bulunmalarıdır. Her birinin dikkat çekici bir başka özelliği, poetik görüşleri ve sanatları üzerinde düşünen, entelektüel bir kimliğe sahip olmalarıdır.

Anahtar kelimeler: Sanat, mizaç, mizaç farklılaşması, Ahmet Haşim, Behçet Necatigil, Necip Fazıl Kısakürek

\section{A Study on reflection of temperament and personality of artists on their works}

\begin{abstract}
Just as a relationship can be established between literary work and reader, history and society, a relationship can also be established between the work of art and the artist's temperament. The existence of criticism methods, which suggest that literary works reflect the feelings and thoughts of the artists, supports this view. According to this view, art is an expression of emotions and reflects the personality of author who produced it. The aim of this research is to examine and exemplify the differentiation of temperament, based on the poems of Ahmet Haşim, Behçet Necatigil and Necip Fazıl, who are famous poets of Turkish literature, in the context of the relationship between art and
\end{abstract}

Bu çalışma, Atatürk Üniversitesi Sürekli Eğitim Uygulama ve Araştırma Merkezi (ATASEM) tarafından 21-23 Haziran 2019 tarihlerinde Erzurum'da gerçekleştirilen “II. Uluslararası Türk Dili ve Edebiyatı Bilgi Şöleni”nde bildiri olarak sunulmuş; daha sonra üzerinde çalışılarak geliştirilmiştir.

Doç. Dr., Ağrı İbrahim Ceçen Üniversitesi, Eğitim Fakültesi, Türkçe Öğretmenliği Bölümü (Ağrı, Türkiye) mcalp@agri.edu.tr, ORCID ID: 00oo-0002-2261-4893 [Araştırma makalesi, Makale kayit tarihi: 22.05.2021-kabul tarihi: 20.09.2021; DOI: 10.29000/rumelide.990132]

RumeliDE Dil ve Edebiyat Araştırmaları Dergisi Osmanağa Mahallesi, Mürver Çiçeği Sokak, No:14/8 Kadıköy - ISTANBUL / TÜRKIYE 34714 e-posta: editor@rumelide.com tel: +90 $5057958124,+902167730616$
Address

RumeliDE Journal of Language and Literature Studies

Osmanağa Mahallesi, Mürver Çiçeği Sokak, No:14/8

Kadıköy - ISTANBUL / TURKEY 34714

e-mail: editor@rumelide.com,

phone: +90 5057958124 , +90 2167730616 
temperament. In this context, one of the works of these three artists, each of whom has a unique understanding of art, has been discussed and their temperaments reflected in these works have been interpreted from the point of view of the reader. In this research carried out with a qualitative research approach, the document review method was used. In the light of the findings obtained, it is concluded that each artist has a different perspective, each of them is under the influence of their own temperament while producing their works, and they reflect the visible and invisible world in a different way. In the poems taken as samples, Ahmet Hâşim's inconsistency with his head, which is his biological existence, and accordingly his self-snoring, Behçet Necatigil's reaction to people's nonchalant attitudes and behaviors and socio-economic injustices in society; inconsistency of Necip Fazıl's inner world with the established order in outer world are prominent themes. As a result, the common aspects of these artists, who have gained a distinguished place in Turkish Literature with their temperaments and their original works, are that they react differently and uniquely to outer world they live in. Another remarkable feature of each is that they have an intellectual identity that reflects on their poetic views and arts.

Keywords: Art, temperament, temperament differentiation, Ahmet Haşim, Behçet Necatigil, Necip Fazıl Kısakürek

\section{Giriş}

Bir anlatım yolu olan edebiyat, güzel sanatların önemli bir koludur. Okuyanlara estetik bir doyum sağlamak amacıyla yazılmış, ya da böyle bir amacı olmasa da biçim ve içerik özellikleriyle buna uyan yazılı ve sözlü eserler, edebiyat kapsamı içinde kabul edilir. Ses ve söz gibi dil malzemelerini kullanarak insan ruhunda estetik dalgalanmalar oluşturan edebiyat bir sanat etkinliğidir.

İnsanoğlu, hayatı boyunca kendini ifade etme ihtiyacı içinde olmuş, bunun için değişik yollara başvurmuştur. Sanat da bu anlatım yollarından biridir. Sanat, İnsanoğlunun çevresinde var olan her şeye karşı gösterdiği bir duyarlılıktır. Her insanın sanata ve sanatkârlığa karşı belirli bir bakışı, belirli bir yatkınlığı, belirli bir yönelişi vardır. Bu yatkınlık ve yöneliş kişiden kişiye değişir. Bundan dolayı sanat şahsîdir.

Sanat eserini değerlendirmek için anlatımcı kuramı kullananlar, sanatı sanatçının benliğinde var olan ayırt edici bir nitelik olarak değerlendirirler. Bu kurama göre sanatçı kendi yaşantılarını, duygularını dolayısıyla kişiliğini anlatan varlıktır. Bu görüşten hareketle, sanatkâr ile ürettiği sanat eseri arasında doğrudan bir ilişki olduğu sonucu çıarılabilir. Yaşar (2018)'a göre, sanatta yaratıcılık, birbiriyle ilintili birçok faktöre bağlı olsa da, sanatta özgünlük ve mizaç arasında çok belirgin bir paralellik bulunmaktadır.

Sanat ile mizaçlar arasındaki ilişki bağlamında anahtar bir kavram olan sanat kelimesinin anlam evrenini belirlemek için sanatın ne olduğu üzerinde düşünmek gerekir. Sanat nassl bir anlama sahiptir? Güzel bir söz işitildiğinde içinde bulunulan ruh hali, sanatın insan üzerindeki etkisini yansıtır. Böyle bir sözün anlamındaki genişlik, anlattığı düşüncelerdeki derinlik, çağrıştırdığı hayallerdeki incelik ve kelimelerin bir araya gelişinden doğan ahenk bakımından diğer sözlerden farklı olduğu görülür. Güzel bir sözün insanda meydana getirdiği etki, güzel bir tablonun, tatlı bir musiki eserinin, zarif bir binanın meydana getirdiği etkiye benzer. Croce'a gore, estetik haz tamamen sempatiden ibarettir. Bu, mimariden, geometrik formlardan vb. elde edilen hazza kadar uzanır. İnsan kişiliğinin olumlu unsuruyla her karşılaştı̆̆ımızda, estetik duygu olan bu parlaklık hissi yaşanır (Croce, 1909). Güzel bir sözün, güzel

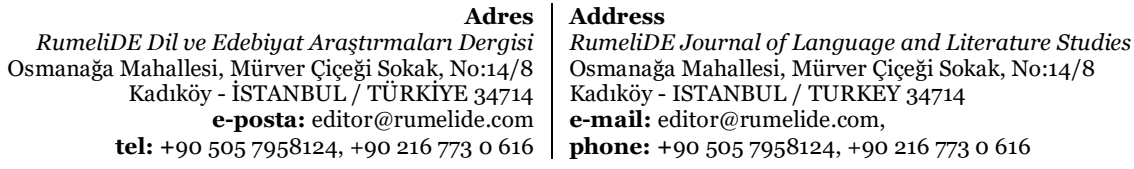


bir tablonun, tatlı bir musiki eserinin, zarif bir binanın ruhlarda oluşturduğu heyecanlar iki şekilde ortaya çıkar: Biri haz, diğeri elem. Neşe verici bir musikî dinlendiğinde ruhlarda oluşan heyecan haz ve memnuniyet şeklinde; dramatik bir vakayı ele alan bir roman veya tiyatro ya da bir ölüm haberini işleyen bir ağıt okunduğunda hissedilen heyecan ise hüzün ve elem tarzında ortaya çıar (Calp, 2017).

Yaşanan çeşitli heyecanlar arasında, bir takım farklar vardır. Bir tablo yahut zarif bir bina veya ustaca yapılmış bir ebru veya hattı seyrederken, hoş bir musikî ya da güzel bir söz, bir hikâye dinlerken veya bunların aksine ürküntü veren bir tablo seyrederken duyulan heyecan, diğer canlılarda da bulunan duyulardan farklıdır. Bu iki duyuyu ayırt etmek için insana has duyulara estetik/bediî heyecan adı verilir. Söz, resim, çizgi, mimarî, musikî gibi çeşitli araçların ruhumuzda bir bedî̀ heyecan oluşturması için hüner sahibi birinin elinden, dilinden, fırçasından, çekicinden çıkması gerekir. İşte bütün bunlardan, güzellik duygusunu meydana getiren şeyin sanat olduğu anlaşllır. O halde sanat, insanda var olan güzellik duygusunu harekete geçiren ve "bediî heyecan" denilen ruhi dalgalanmayı meydana getiren şeydir, denilebilir. Acaba her sanatkâr böyle heyecanları harekete geçirebilir mi? Tolstoy’un sanat eserinin etkisi hakkındaki düşüncelerini ele aldığı (Sanat Nedir?) isimli eserinde: “... bulaşım sanat için en önemli bir şarttır. Bulaşım olmadıkça, eser ne kadar gerçekçi, kuvvetli, şiirsel olursa olsun sanat eserindeki duygu okuyucuya geçmez. Ona göre duygu aktarımını başaran her eser sanat eseridir. Aktarılan duygu önemli ya da önemsiz olabilir, iyi ya da kötü olabilir; vatan duygusu, aşk vb. olabilir.” (Tolstoy, 1904). Sanatçının geçirmiş olduğu hayat serüveni, içine girdiği sanat akımı, yaşadığı coğrafya ve kişiliğinin bir parçası olan mizacı hayata ve topluma bir bakış açısı geliştirmesine yol açar. Bu yöneliş sanatçının sanat anlayışı biçimlendirir. Bu sanat anlayışı, bazen nesilden nesille, sanatkârdan sanatkâra bulaşır. Bu konuda Çetişli: "Tanzimat Edebiyatı’nın birinci neslinde (özellikle Namık Kemal) gördüğümüz o dışa dönük, aktif ve toplumcu ruh hızla ortadan kalkarak ağlamak fiili ile sembolize edilebilecek içe dönük, pasif ve romantizmin teessürüne bulanmış bir ruh hâkim olur." (Çetişli, 2004: 179) derken sanat anlayışlarındaki benzeşme ve farklılaşmaya dikkat çekmektedir.

Edebî eserler ile sanatkâr, okur, tarih ve toplum arasında bir bağ bulunmaktadır. Sanatkârın elinden çıkan her eserde onun izini bulmak mümkündür. Sanatçı, duygu ve düşünceleri diğer insanlardan daha farklı duyan, hisseden ve daha yoğun yaşayan bir karaktere sahiptir. Şair, yaşadıklarını, hissettiklerini, içinde bulunduğu çıkmazları, kakarışıklık ya da trajediyi estetik bir şekilde dışa vurur. Edebî eserlerin yazarların duygu ve düşüncelerini yansıttığını ileri süren eleştiri akımlarının varlığı bu görüşü desteklemektedir. Moran bu konuda şunları dile getiriyor.

"Yazara dönük biyografik eleştiri, sanatçının psikolojisi ve kişiliği ile eserleri arasında sıkı bir bağ olduğu ilkesine dayanır. Bu ilke başlıca iki amaçla kullanılabilir: (1) eserleri aydınlatmak için sanatçının hayatını, kişiliğini incelemek, (2) sanatçının psikolojisini, kişiliğini aydınlatmak için eserlerini bir belge gibi kullanmak. Eleştirmen bu iki yoldan birini ya da ikisini birden kullanabilir. Anlatımcı kuram ise sanatı her şeyden önce duyguların ve yaşantıların dile getirilmesi diye tanımlandığı için, bu kanıda olan eleştirmenler sanatçıya dönerek, onun hayatını, psikolojisini, kişiliğini incelemeye çalışır. Yazarlar eserlerinde kendi kişiliklerini yansıttıklarına göre, bu eserlerden yazarın kişiliğini çıkarabiliriz.” (Moran, 1994: 118-119). Hiç şüphesiz sanatçının eserlerine bakarak kişiliği hakkında sonuçlar çıkarma yaklaşımının bazı sakıncaları vardır. Çıkarılan sonuçlara ne derece güvenebiliriz? Sanatçının kişisel meziyetleri, erdemleri sanat değeri konusunda geçerli ölçütler midir? gibi sorular sorulabilir. Ancak yazara dönük biyografik eleştiri yönteminin görüşlerini de yadsımamak gerekir.

Kişiliğin duygusal özü olan mizaç ile karakter, Cloninger ve Svrakic tarafından şöyle tanımlanmaktadır: "Mizaç, duygulara dayalı becerilerin ve alışkanlıkların bütünleştirilmesinin altında yatan duyumsama,

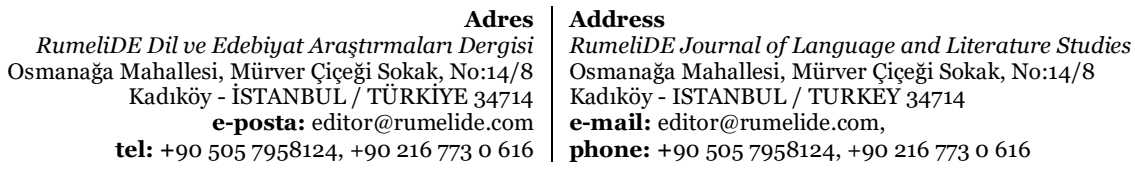


bağlantı kurma ve motivasyon süreçlerine karşlık gelmektedir. Karakter ise, kavramsal öğrenmeye dayanan sembolizasyon ve soyutlaştırma süreçlerine karşllı gelmektedir.” (Cloninger and Svrakic: 2000). Türk Dil Kurumu Türkçe Sözlüğünde huy, yaradılıs, tabiat, karakter olarak tanımlanan mizaç, farklı sözlüklerde de buna yakın anlamlar ile tanımlanmıştır: (1) Huy, yaradılış, tabiat, fitrat, (2) İnsanın doğuştan gelen ve ruh özelliklerinin bütünü. lafsozluk (Erişim tarihi: 23.11. 2019) Bu konuda Selçuk ve Yılmaz mizacın zekâ, cinsiyet, genetik yapı, yaş, biyolojik özellikler gibi üzerinde etki oluşturulamayan içsel faktörler yanında aile, eğitim, sosyal çevre, yaşanılan olaylar, kültür, inanç gibi çok az değiştirilebilen çevresel faktörlerin etkileşimiyle "kişilik"in oluştuğunu ifade etmektedirler. Mizacın yapısal değişmez özellikleri üzerinden gelişen şahsiyetin değiş̧ebilen bir yapıya sahip olduğunu; mizaç, karakter ve kişilik bir ağaca benzetildiğinde; mizaç ağacın tohumu, karakter ağacın kalın dalları, kişilik de ağacın tamamıdır tarzında bir benzetme yaparak aynı cins olsa bile hiçbir ağacın tam olarak birbirinin aynısı olmayacağı gibi mizaca etki eden içsel ve dışsal faktörlerin de, hiçbir birey için aynı olamayacağından dolayı, her insanın da kişilik düzeyinde eşsiz ve biricik olacağını ileri sürmektedirler (Selçuk ve Yılmaz, 2017).

Psikoloji bilimi, bilinçaltıyla doğrudan ilgilenir. İnsanın davranışlarını yönlendiren bilinçli yanıyla birlikte bilinçsiz bir yanı da vardır. Çoğu zaman bilinçaltı, davranışların yönlendirilmesinde bilinçten daha fazla rol oynar. Psikanalistler, sanat eserine bu gözle bakarlar. Sanat eserinin neden ve nasıl yazıldığı soruları sanatçının bilinçaltına inerek anlaşılmaya çalışılır. Freud, nevrotik hastalara uyguladığı tekniklerle sanatçıya yaklaşıp metni değerlendirmede onun bilinçaltını göz önünde bulundururken Jung, metni esas alarak metindeki insan unsuruna ait temel kavramlardan yola çımıştır." (Atlı, 2012: 264). Jung'a göre insan kişiliğini anlamlandırmak için birtakım sorulara cevap vermek gerekmektedir. Bunların başında kişiliğin bölümlerinin neler olduğu, kişiliği harekete geçiren enerji kaynaklarının neler olduğu, kişiliğin nasıl oluştuğu gibi sorular gelmektedir. Kişiliğin oluşumunda sanatkârın gerek doğuştan getirdiği gerekse içinde yetiştiği fiziki ve sosyal çevrenin etkisi ile kazandığı dışsal faktörler yer almaktadır. Jung'ın, Freud'un psikanalizinde yer alan id, ego ve süper ego kavramları yerine bilinç, kişisel ve kolektif bilinçdışı kavramlarını kabul etmesidir. Jung, bireyin kendine özgü oluşturduğu bilinçdışını "kişisel bilinçdışı" şeklinde adlandırmıştır. Kolektif bilinçdışı ise genlerle atalardan devralınan ortak bir bilinçdışını ifade eder. (Nergiz, 2017). Jung, birbirinden farklı yapıların kişiliği meydana getirdiğini kabul etmez. Jung'a göre kişilik bir bütündür. İnsan, kişiliği bir bütünken doğmuştur. Bu nedenle kişiliğini bütünleştirmek için çaba göstermesi gereksizdir. Kişiliği bir bütün şeklinde dünyaya gelen insanın yapması gereken, hayatı boyunca bu bütünlüğü korumaya çalışmaktır. (Nergiz, 2017).

Freud'un sanatçıya bakış açısı ise şu şekilde özetlenmektedir: "Onur, zenginlik, ün kazanmak, yükselmek ve kadınların sevgisini elde etmek ister, ama bu zevklere ulaşma aracından yoksundur. Böylece o da, özlemi yerine getirilmemiş herhangi biri gibi gerçeklikten uzaklaşarak bütün ilgisini ve libidosunu isteklerinin hayal dünyasında yaratılmasına aktarır" (Moran, 2000, 151- 152). Berna Moran, yazarı yazmaya iten etkenin onun bastırılmış dürtülerinden kaynaklanmaktaysa, bu dürtülerin edebiyat eserinde bir şekilde yer bulacağını ifade eder $(2000,152)$.

Moran, Berna (2000). Edebiyat Kuramları ve Eleştiri. İstanbul: İletişim Yayınları.

\section{Çalışmanın amacı}

$\mathrm{Bu}$ çalışmada sanat ile mizaç arasındaki ilişki bağlamında Türk edebiyatında karakteristik kişiliğe sahip üç sanatkâr ele alınmıştır. Türk edebiyatının özgün nitelikli şairlerinden Ahmet Haşim, Behçet Necatigil

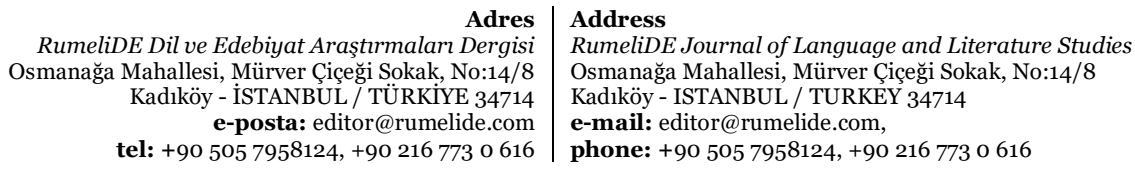


ve Necip Fazıl Kısakürek mizaç ve sanat anlayışları bakımından haklı bir şöhret sahiptir. Sanat çevrelerinde seçkin bir yere sahip bu sanatkârlar gerek mizaç ve sanat anlayışları gerekse eserleriyle edebi topluluklar üzerinde etkili olmuş, birçok araştırmaya konu olmuştur.

Gerek nesirleri gerekse şiirleri ile kendine has bir tarza sahip Ahmet Haşim, Türk edebiyatının önemli isimlerinden biridir. Mizacının özgün olması yanında özellikle şiirini kapalı bulanların eleştirenlere cevap olarak yazdığı Şiir Hakkında Bazı Mülahazalar başlıklı poetikasındaki 'Şiir anlaşılmak için değil, duyulmak içindir.' söylemiyle Türk edebiyatında iz bırakmıştır.

Behçet Necatigil, ise büyük şehirlerde sosyal, psikolojik ve ekonomik sıkıntılar içinde sıkışan sade insanların çektiği acıları dile getiren bir şairdir. Dile getirdiği duyguların okuyucu üzerinde karşılık bulması, samimi oluşundan ve bizzat bu duyguları yaşamış oluşundandır. Okuyucu, onun şiirlerini okurken içinde bulunduğu kendi yaşanmışlıklarını bulur ve sanatkârla duygudaşlık içine girer.

Necip Fazıl'da kalabalı̆̆ın içinde kendini yalnız hisseden insanların şiirini yazmış ve bu noktada Kaldırımlar şiiri ile özdeşleşmiştir. Necip Fazıl dış dünyanın gündelik tartışma ve telaşlarından çok zihnini meşgul eden mistik, psişik ve metafizik sorunlarla meşgul olmuş bir sanatkârdır. Şiirlerinde, ruhi burkuntularını yansıtması yanında içinde yaşadığı toplumun bunalımlarıyla da ilgilenen Necip Fazıl, bunları şiir, hikâye, tiyatro, deneme ve gazete yazılarında etkili bir şekilde okuruna aksettirmiş; bu arada şiir sanatı üzerine örgütleştirdiği poetikasıyla seçkin bir yer edinmiştir.

Çalışmanın amacı, Türk edebiyatının ünlü üç şairinin birer şiiri bağlamında sanatkârın mizacı ile sanat eseri arasında bir ilişki bulunup bulunmadı̆̆ını belirlemeye çalışmaktır. Bu amaç doğrultusunda aşağıdaki sorulara cevap aranmıştır:

1. Ahmet Haşim’ın Başım adlı eseri ile sanatkârın mizacı arasında nasıl bir ilişki vardır?

2. Behçet Necatigil’ın Dışarda adlı eseri ile sanatkârın mizacı arasında nasıl bir ilişki vardır?

3. Necip Fazıl’ın Bu Yağmur adlı eseri ile sanatkârın mizacı arasında nasıl bir ilişki vardır?

\section{Yöntem}

Nitel araştırma yöntemine göre desenlenen bu çalışmada, veriler derinlemesine betimlenmeye ve yorumlanmaya çalışılmıştır. (Yıldırım ve Şimşek, 2013)

\section{Araştırma deseni}

$\mathrm{Bu}$ araştırmada nitel araştırma yöntemlerinden örnek olay tarama modeli kullanılmıştır. Örnek olay tarama modelleri, evrendeki belli bir ünitenin (birey, aile, okul, hastane, dernek ve benzerlerini), derinliğine ve genişliğine, kendisi ve çevresi ile olan ilişkileri belirleyerek o ünite hakkında bir yargıya varmayı amaçlayan tarama düzenlemeleridir. Bunlara monografi çalışmaları da denir. Bu tür düzenlemelerle toplanan bilgiler yalnızca inceleme konusu ünite için geçerli olup onun ötesinde bir genelleme amacı taşımaz. Ancak incelenen örnek olay sayısının çoğalması ile genellenebilirlik de sağlanabilir (Karasar, 2016: 119).

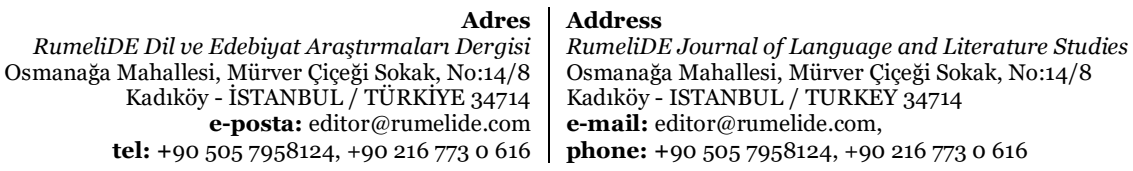




\section{Verilerin toplanması ve analizi}

$\mathrm{Bu}$ araştırmada nitel araştırmalarda kullanılan veri toplama yöntemlerinden doküman inceleme yöntemi kullanılmıştır. Araştırmanın verileri Ahmet Haşim, Behçet Necatigil ve Necip Fazıl'ın eserleri ile bu sanatkârlar hakkında yazılmış çalışmalardan elde edilmiştir. Araştırma, bu sanatkârların birer şiiri ile sınırlı tutulmuştur.

\section{Bulgular}

Bu bölümde Ahmet Haşim, Behçet Necatigil ve Necip Fazıl'ın eserleri ile mizaçları arasında ilişki hakkında elde edilen bulgulara yer verilmiştir.

\section{Ahmet Haşim'ın Başım adlı eseri ile mizacı arasında ilişki}

Türk Edebiyatında sembolist anlayışın en başarılı örneklerini veren şair Ahmet Haşim'dir. O, yaşadığı dönemin ilginç şahsiyetlerinden biridir. Çeşitli sosyal ve siyasal çalkantıların vuku bulduğu, millî bir edebiyat anlayışının bütün sosyal alanları kapsadığı ve yönlendirdiği yıllarda Hâşim, kendi tabiriyle züccâc-ı san’at ü fikret ile örülü fildişi kulesinden dünyaya bakar ve sanatını, bu kapalı âlem üzerine kurar. Onun mizacı ve eserleri, içinde yaşadığı topluma tamamıyla tezat teşkil eder. Tanpınar'ın ifadesiyle o, 'Efkâr-ı umûmiyeye hiç tâviz vermeyen adamdır.' (Hisar, 1963). Hâş̧im’in bu tutumu, mizacından doğmaktadır. Ayrıca yetişme tarzı ve annesini küçük yaşta kaybetmesi gibi bir takım dış faktörler de, onun psikolojisinin bu yönde gelişmesine yol açmıştır. Toplumdan kaçış, egzotik yerlerin özlemini çekiş, kendi içine kapanış Haşim’in birçok şiirinde görülür.

Ahmed Haşim, "Ne kendi kimseye benzer, ne kimse kendisine sözü ile anlatılabilir. Şiirleri kadar huylarının, kültürünün, nüktelerinin, nefret ve sevgilerinin, hülasa mizacının da bambaşkalığı dillere destan olmuştur." (Hisar, 1963). Hâşim’in sanat anlayışının temelinde şiirin tamamen kişisel bir alan olduğu görüşü yatar. Öyle ki Çanakkale savaşına bizzat katılmış olmakla birlikte ne bu savaşla, ne de herhangi bir tarihsel, toplumsal olayla ilgili tek bir dize yazmıştır. Okay, Ahmet Hâşim'in şiirinin kaynaklarını (1) Şairin ferdi hayat ve şahsiyetinden gelen unsurlar, (2) Türk şïr geleneğinden gelen unsurlar, (3) Fransız sembolizminden gelen unsurlar olmak üzere üç noktada toplamaktadır (Okay, 2005).

Ahmed Haşim’in Başım şiiri onun mizaç ve psikolojisini yansıtması bakımından dikkat çekicidir. Aşă̆ıda sanatkârın ferdi hayat ve şahsiyetini yansıtan şiirlerinden Başım şiirine yer verilmiştir. Şüphesiz Ahmet Hâşim'in mizaç ve psikolojisini yansıtan başka şiirleri de bulunmaktadır. Burada Başım şiirinden hareketle onun kişiliğinin eserine yansıyan yönü üzerinde durulacaktır.

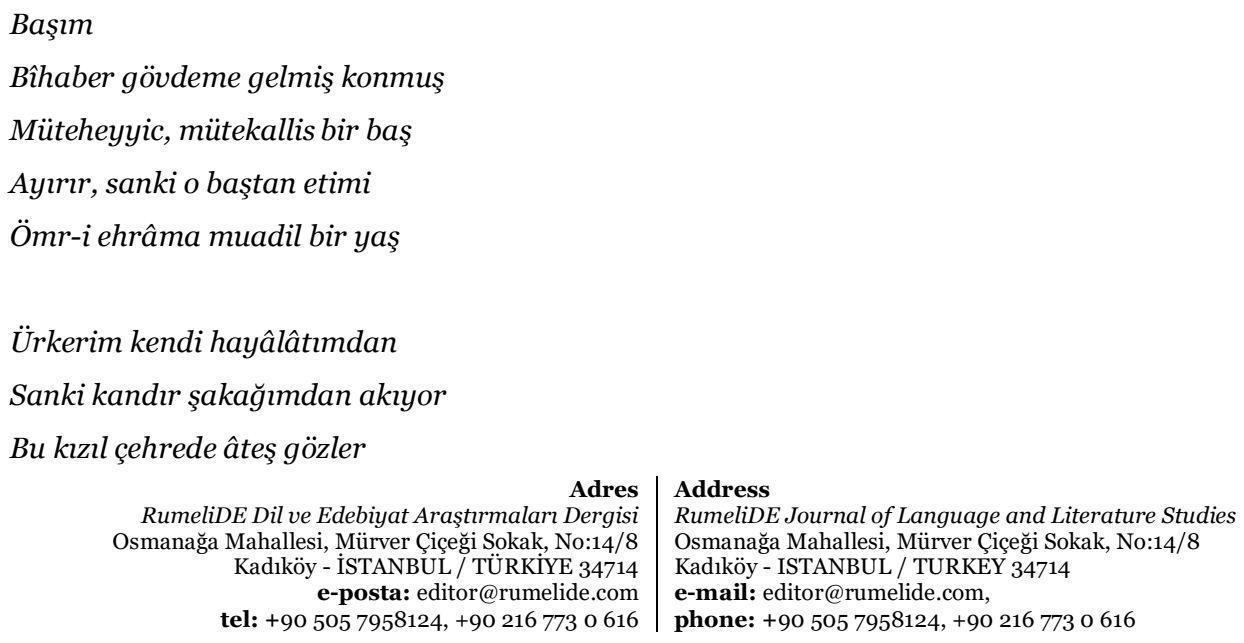


Bana güyâ ki içimden bakıyor

Bu cehennemde yetişmiş kafaya

Kanl bir lokmadir ancak mihenim

Âh, yâ Rabbi! Nasıl birleşti?

Bu çetin başla, suçsuz bedenim.

Dişi, turnakları geçmiş etime

Gövdem üstünde duran ifritin

Bir küçük lahzâ-i arâma fedâ

Bütün âlâyişi nâm u sıytin (Hayat Mecmuası 1927, 20: 5.)

Adeta Haşim’in içinde gizli bir cin vardı. Bu cin onun için hem ilham hem de sıkıntı kaynağıydı. A. Haşim'in simasını Yusuf Ziya Ortaç şöyle anlatır: Büyük, firlak bir alın. Sonra, yine bu alın kadar büyük, sağlam, ortası çukur, firlak bir çene. Kaşlar, yukarı doğru çekilmiş, uçları biraz kırık iki şeytan çizgisi. Göz bebeklerinde, altın, demir, bakır karışık bir maden parçasının bütün renk ışıkların görürdünüz. Yüzü, taşkın bir neş'e, taşkın bir öfke, taşkın bir arzu ile kırmızıydı (Avcu, 2019: 95),

Ürkerim kendi hayâlâtımdan

Sanki kandır şakağımdan akıyor

Haşim, ölünceye kadar o zeki baştan ürktü. Onun gençliğinde, pudralı yanak, kozmetikli bıyı, briyantinli saçtı güzel sanılan! Şair, bu korku içinde, son nefesini verdiği kırk yedi yaşına kadar, sevmenin, sevilmenin hasreti içinde, yapayalnız yaşamıştır. http://earsiv.sehir.edu.tr (Erişim Tarihi: 26.02.2020).

Kaplan, onun mizacıyla ilgili olarak şunları ifade eder: "Şahsî psikolojisi de Hâşim'de bu duyguyu beslemiş olmalıdır. Annesi ve babası Arap olan Hâşim, milliyetçilik fikirlerinin hâkim olduğu bir devirde yaşadı. Sosyal çevre ile anlaşamayarak kendi içine ve sanat âlemine çekildi. Çocukluğuna ait şuuraltı intibalarının da bu hususta rolü olduğuna kaniîm.” (Kaplan, 1978: 143).

Haşim'in kendine has mizaç ve karakterini hazırlayan bazı ailevi, sosyal ve ekonomik faktörler bulunmaktadır. Onun küçük yaşlarda sıkıntılı günler yaşamış olması, İstanbul'a taşındıktan sonra elverişli bir sosyal ortam bulamaması gibi etkenler, sanatkârın hayata ve topluma karşı bedbin-pesimist bir bakış açısı oluşturmasına yol açmıştır denilebilir.

Haşim’in mizacının bir yönünü yansıtan aşă̆ıdaki mısraları Kaplan şöyle yorumlamaktadır: "Din ile şâirâne hayâller arasında derin bir fark vardır: Dindar imanlıdır; dinin arz ettiği hayâllere inanır ve o bu dünyada yaşadığı hayatı, dinî görüşüyle açıklayarak mânâlı bulur. Bundan dolayı dindar ümitsiz ve bedbin değildir. Dinin yerini alan şâirane hayâllerde bu iman ve huzur yoktur. Çok güzel hayâller yaratan Hâşim, dâima mustariptir. Zirâ tasavvur ettiği hayâllerin bir hakikate tekabül ettiğinden emin değildir." (Kaplan, 1978: 144-145) O Belde şiirinde kendi kendisine şöyle sorar:

O belde

Hangi bir kut'a-i muhayyelde?

Hangi bir nehr-i dûr ile mahdûd?

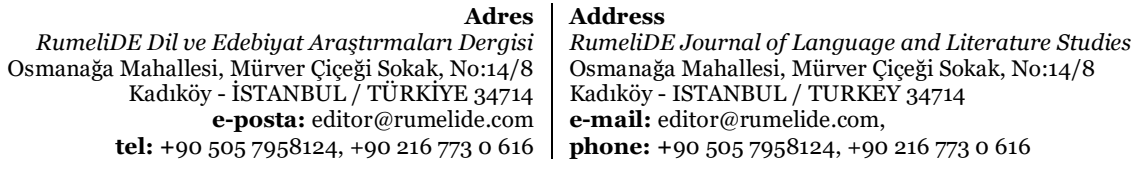


Bir yalan yer midir veya mevcûd

Fakat bulunmayacak bir melâzı-ı hulya mı?

Haşim, kavuşma neşesi yerine ayrılık acısını yaşayan bir ömür sürmüştür. Nitekim hicran duygusunu ifade ettiği "Şafakta" şiiri buna tipik bir örnek oluşturur:

Dönsek mi bu aşkın şafă̆ından

Gitsek mi ekalim-i leyâle ${ }^{2}$

Bizden daha evvel erişenler

Ağlar bu gün evvelki hayale

Sanatkârın bu yaklaşımında, onun benimsediği sanat akımı, geçirmiş olduğu hayat serüveni ve kişiliğinin bir parçası olan mizacının önemli bir etkisi olduğu söylenebilir.

\section{Behçet Necatigil'ın Dışarda Adlı eseri ile mizacı arasındaki ilişki}

Behçet Necatigil, şiir üzerine düşünen, yeni ve özgün şiirsel arayışlara giren ve poetik görüşleri ile kendisinden sonra gelen birçok şair üzerinde önemli tesirler bırakan bir şairdir. Necatigil’in anlatmaya ve hikâye etmeye dayalı bir poetik anlayış geliştirdiği görülür. Şair, parantez göstergesiyle açımlanan poetik ürünlerinde, şiirde ne kadar çok şey anlatılırsa anlam zenginliğinin o kadar fazla olacağına inanmaktadır (Tunç, 2019). Ne var ki şair bu anlayışının tam zıddı sayılacak bir yaklaşıma da sahiptir. Necatigil şiirlerinde bilinçli bir şekilde eksiltmeler yapar, şiirini tamamlamaz. Okur, sanatçının şiirlerinde tamamlanması gereken boşluklarla karşılaşır. Bu bakımdan okurun şiirde var olan espriyi yakalayabilmesi için her an tetikte olması beklenir.

Şair, bu bilinçli tavrının okur tarafından da algılanması için çaba gösterir ve boşluk koyduğu yerleri düşünce çizgisi (- -) ile açığa vurur. Söz konusu uygulamada pasif okurun yerini, Umberto Eco'nun Anlatı Ormanlarında Altı Gezinti adlı kitabında kavramsallaştırdığı, yazarla metnin yeniden inşası konusunda işbirliğine giden örnek okur alır. Nitekim Necatigil, düşünce çizgisi ile okuru metni anlamlandırmada işbirliğine çağırdığı yerlerin de altını çizmiş olur (Tunç, 2019). Necatigil'in şiirinin en belirgin özelliği, özgün bir şiir dilini oluşturmasıdır.

Şiirde biçim, mısralarının düzeni, kafiyelerin sıralanışı, benimsenen ölçü; kullanılan dil ve anlatımdan oluşur. Şiir yoğunlaşttrmadır, biçim titizliğidir diyen Necatigil'e göre durulmuş özler, kesin biçimlerini beraberlerinde getirirler. Ona göre, asıl olan duygudur, sanatta santimantalizm önemlidir. Yaşanan hassasiyetin dil kalıbına dökülmesi bir sonraki aşamadır. "Sözcükler üzerinde titizlikle durur, şïri az kelimeyle kurmak, şïri korumaktır. Kullandı̆̆ı sözcüklerin anlamları kadar ses değerlerine de önem verir sözcüklerin değişik anlamlarından yararlanarak anlam çoğaltmaları yapar. Sözcüklerin hecelerini ayrı yazmak, sözcükleri eğik çizgiyle bölmek (“Ümit/sizsiniz, susma/k”), merdiven şiir teknikleriyle şiirin anlam boyutunu genişletir.” (Özpalabıyıklar, 2015: 123).

Necatigil şiirlerin formunu çok farklı yollarla biçimlendirir. Spitzer, edebî eserin dış görünüşü ve dilinin bir iç formun dışta kristalize edilmiş hâlinden başka bir şey olmadığı düşüncesindedir. (Moran, 1994). Biçim, eserde yer alan bütün ögelerin birbirine bağlanıp örülerek meydana getirdikleri düzendir. Şiirin

ekalim-i leyâl: Gece ülkeleri

RumeliDE Dil ve Edebiyat Araştırmaları Dergisi Osmanağa Mahallesi, Mürver Çiçeği Sokak, No:14/8 Kadıköy - ISTANBUL / TÜRKIYE 34714 e-posta: editor@rumelide.com tel: +90 $5057958124,+902167730616$
Address

RumeliDE Journal of Language and Literature Studies

Osmanağa Mahallesi, Mürver Çiçeği Sokak, No:14/8

Kadıköy - ISTANBUL / TURKEY 34714

e-mail: editor@rumelide.com,

phone: +90 $5057958124,+902167730616$ 
özü kadar, sunuluşu, söze dönüştürülmesindeki içtenlik, yakınlık, ses ve anlam bakımından şairin gösterdiği ustalık da önemlidir.

Kendine özgü bir üslup anlayışına sahip olan Necatigil, Türk edebiyatında birçok şiire imzasını atmıştır. Şiirlerinde oluşturduğu yeni çağrışım imgeleri, onun dili ne kadar titizlikle kullandığının bir göstergesidir. Şairin oluşturduğu her çağrışım imgesi, anlam derinliğine sahip olan ve yaşamın bir parçasını içinde barındıran bir yapıdadır (Şahin, 2006: 74). Necatigil'in şiirleri edebiyat sanatı bakımından zengin imgelere sahiptir. Bu zengin imgelerle dolu şiirler Necatigil'in ruh dünyasının ve yaşadıklarının dışa yansımasıdır. Şimşek'e göre Behçet Necatigil, zengin şiir birikimiyle büyük oranda 'ben' şairidir. Bunu saklamaya ihtiyaç duymaz. Korkuları, kaygıları, coşkuları, beklentileri ve hayal kırıklıklarıyla saydam bir portre çizer. İnsan yanlarının şiirine yansımasından rahatsız olmaz. İçtenliğini şairliğine yoldaş kılar (Şimşek, 2018). Yaşadığı dönemde toplumcu şiir yazmamakla, çağının tanı̆̆ olmamakla eleştirilmiş, özellikle Yaz Dönemi adlı kitabından sonra yazdı̆̆ı şiirlerle gittikçe anlamı gündelik dilin dışına, bildirişim işlevinin ötesine taşımıştır. (Şişmanoğlu, 2003: 1).

Necatigil'e göre, bir şair, şiir yaşamı boyunca üç burçtan geçer: Gurbet, hasret ve hikmet burçları. Bir arayış dönemi olan "gurbet burcu”ndaki şair, beğendiği sanatçların etkisi altındadır ve Ziya Osman, Cevdet Kudret, Necip Fazıl gibi şairlerin etkisindedir. Kapalıçarşı'da evlilik, cinsellik, mutlu aile düşleri, doğa ve yaşama temaları işlenirken Çevre'de yalnız insanın dramı ve aile kurma özlemi artar. ... Arada ve Dar Çă̆ (1960), 'arada' kalmış insanın durumunu ve 'dar çağlar'da yaşamanın zorluğunu anlatır (Özpalabiyıklar, 2015: 122).

Behçet Necatigil dendiğinde hemen akla geliveren $e v$ ve aile gibi gözde konuların işlendiği şiirler yer alıyor. 1961 de yaptığı bir konuşmada şöyle diyor: "Ben mum alevinde pervane gibi hep aynı odakta yazdım şiirlerimi: ev ve her günkü yaşamalar (...) toplumun ve imkânlarımın bana bağışladığı dar dörtgende gözlerimi her açtıkça karşımda büyük şehrin orta-fakir sınıf, ev, aile çevrelerini buldum.” (Necatigil, 1961). Onun sanata yüklediği işlev ve şahsi eğilimini yansıtması bakımından Evler şiiri anlamlıdır.

Evler

Vurulmuş vurgunlarn yücelttĭgi evlerde

Kalbi kara insanlar oturdu.

Gündelik korkularm çökerttiği evlerde

o fikara insanlar oturdu.

...

Evlerin içi oda oda üzüntü,

$\cdots$

Evleri felaketler taunlar gibi süpürdü.

Kaderden eski firtmalar gibi...

Burada Dışarda şiirinden hareketle onun kişiliğinin eserine yansıyan yönü üzerinde durulmuştur.

Dişarda

Yandı sokak lambaları mum alevi pervane

Şeytanca sirttur fosforlu camlar

Gördüm zifir sarısını dükkân vitrinlerinde

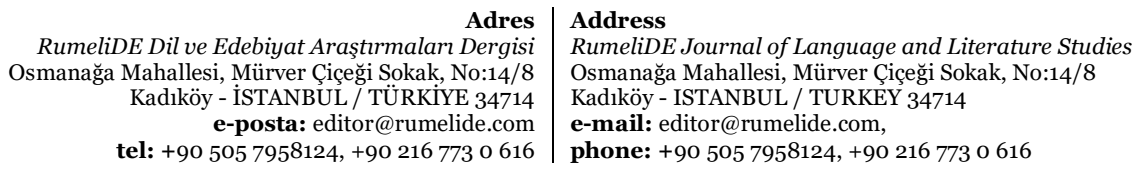


Belliydi, biliyordu, bezgindi

Evimize gidelim.

Alay eder, küçümser; eziliriz girsek

Hep paraya saygı camlar

Camların ardı sırnaşık, kirli

Yapışkan çarpar

Evimize gidelim.

Bir yanı var ömrümüzün kırık

Farlar büyültür gecede

Garipsi türkülere özgün

Başlamadan yollar

Evimize gidelim.

Pahalı vitrinler aracılığıyla verilen ve onu ürküten dış dünya, şair için iticidir. Necatigil, kendisiyle yapılan bir söyleşide içerde/dışarda olmaya ilişkin şunları söylemektedir: "Bizi biz eden kaçışlardır, kenara çekilişlerdir. Kalabalıkların ortasında kendi yalnızlı̆̆ını sürdürüp bir kozayı olgunlaştırmaktır. Bütün çalışmalar birer yalnızlığı gerektirir. İçinde birikene eğilen, 'içeriyi’ dinleyen kişi, dışarda söylenenlerden daha çok şey duyar" (Düzyazılar II 38).

Burada zenginlik, doğrudan doğruya değil, göze hitap eden objelerle, vasıtalı olarak ortaya konulmuştur. Daha ilk mısrada, zenginlikle fakir arasındaki tezat, göz önünde küçük bir tablo vücuda getiren bir imajla ifade olunuyor. Şeytanca surttıyor fosforlu camlar dizesi, zengin(lik)lerin fakirler üzerindeki etkisini yansıtır. Şair, bulunduğu ortamdan rahatsızdır; evine dönmek ister. Evleri dış dünyanın baskısı altında bunalan sıradan insanın sığınabileceği tek mekân olarak düşünür (Kaplan, 1978: 215).

Behçet Necatigil, Dışarda şiirinde zenginler ve fakirler arasındaki tezadı dile getirmektedir. Şairin dile getirdiği bu duyguyu derinden yaşıyor olması, şiirin okuyucu üzerindeki etkisini artırmaktadır. Dışarda şiiri, muhteva, şekil ve üslup bakımından ustaca kurulmuş bir tezada dayanıyor: İlk bakışta görülen, sokak ile $e v$ arasındaki tezattır. Şair sokaktan nefret ediyor, korkuyor ve evine dönmek istiyor. Şairin mizaç olarak çekingen bir insan olması bu imajı canlı bir şekilde aktarmasında etkili olmuştur.

Sokak veya vitrinlerin onda bu duyguları uyandırmasının sebebi, fakirliğinden utanma ve ezilme hissidir. Camlar yani güzel eşyaları teşhir olunduğu dükkân vitrinleri, ancak paraya karşı saygı duyarlar. Fakirlerin böyle yerlerde işleri yoktur. Onlar bu dükkânlarda birine girecek olsalar, belki de alaya alınacaklar ve küçümseneceklerdir. İyisi mi onların önünde hiç dolaşmamalı. Kendi evinde, kapalı kapılar ardında, kendi derdiyle hemhal olmalı (Kaplan, 1978: 215).

Necatigil, hayata katlanma, anlaşılamama, yalnızlık, hayalle gerçek arasında sıkışıp kalma gibi yazgısal görünüşlerle, bir tragedya kahramanına benzer. Şimşek'e göre Necatigil'in şiirlerinde 'şair özne', gündelik hayatın getirdiği zorluklara, şiirini paylaşmayan insanlara ve yalnızlı̆̆a katlanmak durumundadır. Anlaşılamamayı ve vefasızlı̆̆ sineye çeker (Şimşek, 2018). Behçet Necatigil, bütün bunlara rağmen içinde yaşamakta olduğu topluma ait sıkıntılara duyarlıdır. Zor Geçit adlı şiirinde fakirliğinden bahsederken kendi dışındakilerle duygudaşlık içindedir:

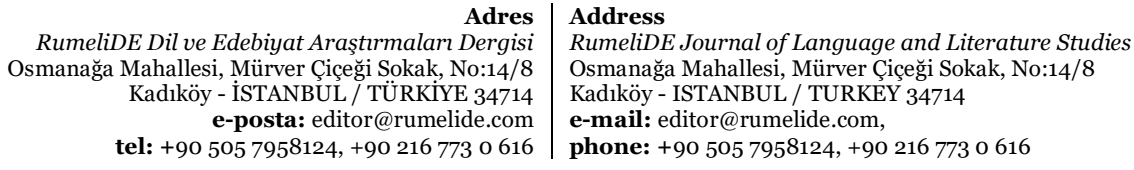


Seni, beni üzen dertte

Çarpar bir milletin kalbi,

Halkın çoğu bizim gibi

Bunun lafinı etmekte.

Kendine özgün tutuk söyleyişiyle tedirginliğini, sıkıntılarını, korkularını, öfkelerini yansıtırken yalnız, biraz kırgın, içine kapanık bir kimlik sergiledi. Çok kendine özgü duyarlılığı şiirine ulaşılması güç bir derinlik kazandırdı. Necatigil şiirlerinin konularını çoğunlukla kendinden ve çevresinden alır, ancak bunları farklı anlatım teknikleriyle işler (Kaplan, 1978: 215).

Çağın Tanığı Olmak başlıklı şiirin "Diş diş / Kalıntı çağ mazgalları / Sonra yeni katmanlar / Bir intihar gibi içerde.” mısralarındaki diş diş, kalıntı çă̆ mazgalları, yeni katmanlar ve intihar sözcükleriyle şairin içerisinde bulunduğu ruh hâlini yansıtmaktadır. Bu sözcüklerin bir anlam evreni oluşturduğu ve olumsuz duygular çağrıştırdığı açıktır. Şairin bu tür sözcüklere yer vermesi, onun kendi ruh hâlinin bir yansımasıdır. Şimşek'e göre şiir her şeyden önce bir ifşa serüvenidir. İç dünya ile dış dünya arasında gerçekleştirilen bir alışveriştir. Şair, mısra aralarına kendini saklamaya çalışsa da, şiirin şairini ele vermek gibi köklü bir alışkanlığı vardır (Şimşek, 2018).

\section{Necip Fazıl'ın Bu Yağmur adlı eseri ile mizacı arasındaki ilişki}

Necip Fazıl Kısakürek (1904-1983), yirminci yüzyıl Türk şiir sanatına getirdiği yeni ses ile birlikte metafizik ve mistik yapıda yeniliğin temsilcilerinden biri olmuştur. Onun ilk şiirlerinden itibaren sanatını korku, vehim, boşluk, yalnızlık, ölüm, şüphe, sebebi anlaşılmayan ıstıraplar, kendini aşma duygusu, bilinmeyeni bilme arzusu, öznenin iç dünyasının ifadesi etrafinda oluşan metafizik karakterli duygu ve düşünceler kurar (Gariper, 2005: 68). Yalnızlık, korku, ölüm, Allah, evren, insanın iç dünyasındaki çatışmalar, ruh ve madde, Necip Fazıl’ın ilk dönem eserlerinde kullanılan başlıca temaları oluşturur (Erol, 2018).

Zira o, yeni dönemde önceki ylllara ait içsel problemlerini büyük ölçüde halletmiş ve dikkatini dış dünyaya vererek toplumsal konulara ağırlık vermiştir. Artık şiirini kendi ideolojisinin emrine veren (Kolcu, 2008: 197) bir Necip Fazıl vardır. Hayatının sonuna kadar dinî inançlarının yönlendirmesiyle toplum sorunlarını merkeze alan bir sanat anlayışının öncü ismi olarak zihinlerdeki yerini alır (Çakmaker, 2014: 70).

Necip Fazıl, Ahmet Kutsi Tecer ve Ahmet Hamdi Tanpınar'la birlikte halk şiirinin şekil özellikleriyle XIX. yüzyıl Fransız şiirinin getirdiği değişik imkânları kaynaştıran usta bir şairdir. O, hece ölçüsünü, kendinden önceki kullanış biçimlerinin ötesine götürerek günümüz insanına ters düşmeyen bir duyarlılıkla işledi. Necip Fazıl, çağındaki dışa yönelen bakış açılarına tepki olarak insanın iç dünyasına yöneldi. Bu yüzden şiirlerinin yeni ve orijinal görülen psikolojik bir derinliği vardır. Aşă̆ıdaki parçada görüldüğü gibi, dünyaya ait önemsiz bir objeden bir motiften hareketle başlayan şiir, birden bire bir derinlik kazanarak iç âleme yönelir.

Bu Yağmur

Bu yağmur... bu yă̆mur... bu kaldan ince

Nefesten yumuşak yă̆an bu yağmur...

Bu yağmur... bu yă̆mur... bir gün dinince

Aynalar yüzümü tanımaz olur

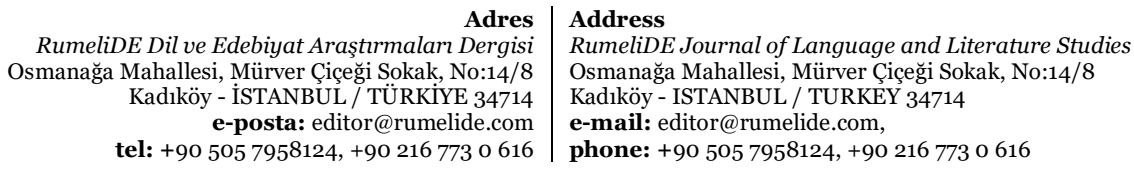


Bu yağmur kanımı boğan bir iplik,

Karnımda acısız yatan bir bıçak.

Bu yağmur, yerde taş ve bende kemik

Dayandıkça çisil çisil yă̆acak

Bu yağmur... bu yağmur... cinnetten üstün;

Karanlık kovulmaz düşüncelerden.

Cinnetin beynimde yaptığı düğün

Sulardan, seslerden ve gecelerden. (Çile: 1976).

Necip Fazıl, şiirlerinde ferdi bunalımlarını anlatan bir şairdir. Onun ıstırabı daha ziyade ferdi ve metafizik bir mahiyet arz eder. N. Fazıl'a hayatı boş, karanlık ve karışı gösteren ruhi sıkıntılar dıştan değil, içten kaynaklanmaktadır. Şiirinde dış âlem, kendi iç âleminin objektif karşılığını oluşturur.

$\mathrm{Bu}$ Yağmur şiirinde tekrarlanan kelimeler, onda sabit bir ruh halinin varlığının göstergesidir. $\mathrm{Bu}$ yağmur kelime grubu, âdeta musallat bir fikir olarak sık sık tekrarlanır. Şair bu ifade tarzıyla, şiirinde psikolojik bir yoğunluk oluşturmaktadır. Şiirde yer yer karşılaşılan tekrarlar şairin iç gerilim ve sıkıntılarının yoğunluğunu hissettirir; bu yağmur şairin karnında yatan acısız bir bıçaktır.

Necip Fazıl'ın kendini telakkisi oldukça trajiktir. Bu hususu, Kaldırımlar adlı şiirinde açı olarak görmekteyiz. N. Fazıl'ı içindeki azap verici bazı karışık duygular rahatsız eder.

Bu yağmur kanımı boğan bir iplik,

Karnımda acısız yatan bir bıçak. “

mısraları buna tipik bir örnek oluşturur.

İnsan, tabiatta kendi iç âleminden bir parça, bir unsur görme eğilimindedir. İnsan, iç âlemindeki sonsuz duygu, düşünce, sıkıntı ve hafakanlarını ifade ederken dış âlemin çeşitli objelerinden yararlanır. Bir başka ifadeyle tabiattaki çeşitli durum ve olaylarla kendi iç dünyası arasında ilişki kurar. Yani dış âlemin değişik durum ve olaylarını (objenlerini) kendi iç âleminin (süjesinin) ifadesi için vasıta olarak kullanır.

Necip Fazıl da Bu Yağmur başlıklı bu şiirinde dışa dönük maddi unsur olarak kıldan ince, nefesten yumuşak yağan yağmuru alır. Ve bu yağmurun cinnetin beyninde yaptığı düğün olduğunu ifade eder. Böylece dış âlemin bir unsuru (yağmur) onda iç’e ait bir psikolojik derinliğe ulaşır. Şair için için ağllyor, istırap çekiyor:

Bu yağmur, yerde taş ve bende kemik

Dayandıkça çisil çisil yağacak

Burada, şairin kâinata, canlı varlıklardakine benzer bir rûh izafe ettiğine de işaret edelim. Cansız varlıkları canlıymış gibi göstermeye antropomorfizm denilmektedir. Bu şiirde taş, insan yahut genel olarak canlılara mahsus olan dayanma, tahammül etme özelliğine sahip kılınıyor.

$\mathrm{Bu}$ şiirde şairin kendi kendisiyle mücadele halinde olduğunu görüyoruz: İç sıkıntısı, gerilim, hafakan mevcut; psikolojik bir gerilim var. Şair kendi iç trajedisini topluma ve kâinata yansıtır: sanatçının

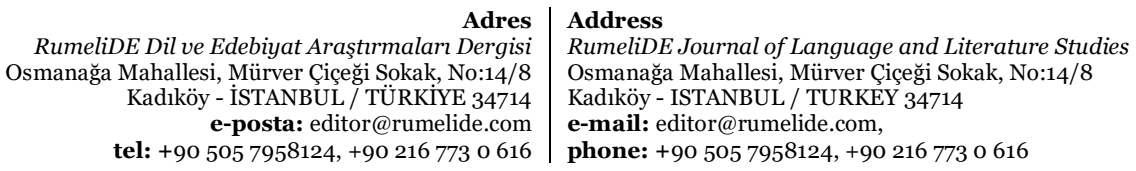


kendisi birçok bakımlardan herkesi aşan, keskin sezişleri, ince duyarlılığı, yüksek nitelikleriyle derinliklere inen, yücelere çıkan bir üstün sanatçı kişiliğine sahiptir.

\section{Tartışma ve yorum}

Her biri nevi şahsına münhasır bir mizaca sahip olan bu sanatkârlar arasında mizaç farklılıkları kadar sanat anlayışları bakımından da farklılık bulunmaktadır. Sanatkârların yaklaşımlarında, onların benimsediği sanat akımı, geçirmiş oldukları hayat serüveni ve kişiliklerinin bir parçası olan mizaçlarının etkisi olduğu söylenebilir. Behçet Necatigil, şiirlerinin çoğunda açıkça görüldüğü üzere, kapalı, içe dönük bir tiptir. Dış âlem onu rahatsız eder. Bu tip insanlar, huzur ve sükûnu umumiyetle kendi içlerinde, hayal âlemlerinde veya varlık ötesinde ararlar. Dışarda şiirinde görülen sokak-ev tezadı ve eve kaçma temi Necatigil'in ilk şiir kitabı olan Kapalı Çarşı da vardır. Her bir şiirinde farklı bir durumu betimlemeye çalışan Behçet Necatigil’in şiirlerini çözümlemek, edebiyat dünyası için önemlidir. Bu hal Ahmet Haşim için de geçerlidir. İçinde bulunduğu fiziki ve sosyal ortam onu sıkar; daima muhayyel bir âlemin özlemini çeker. Öte yandan Necip Fazıl Kısakürek’in şiirlerindeki mana derinliğine nüfuz edebilmek için devrin sosyal ve siyasi şartları ile birlikte şairin hayatının bilinmesi, etkisinde kaldığı sosyal, siyasi ve tasavvufi çevrenin çok iyi analiz edilmesi gerekmektedir. Bu husus Haşim için de söz konusudur.

Sanatkârların mizacı ile sanat eserleri arasında doğrudan ilişki bulunduğunu ileri sürenler yanında ilişkinin dolaylı olduğunu, sanat eseri üzerinde tarih ve toplumsal şartların da etkili olduğunu ileri sürenler bulunmaktadır (Moran, 1994: 118-119). Sanatkârların mizacı ile sanat eserleri arasında ilişki bulunduğunu ileri sürenlerin tezlerini destekleyecek şu görüşler ifade edilebilir:

Sanatkâr, mizacının izlerini eserine öylesine işler ki eser ile sanatkâr özdeşleşir. Eser, sanatkârın bir elçisi, hatta kendisi olur. Sanatkârın mizacı eserine öylesine yansır ki siz eseri sanatkârdan ayıramazsınız. O eserde sanatkârın ruh halini, hayat tarzını bütün ayrıntılarıyla bulursunuz. Mesela sanatkâr; hayata umutla, şevkle ve heyecanla bağlanmışsa; siz onun eserlerinden neşe, sevinç, şen ve şakrak bir havayı solursunuz, bunun tersi de doğrudur. Her yerde ve her şeyde hüzünlü, kasvetli, karanlık, çürük, boş ve ezici bir taraf arar ve bulur. Bunun sosyal şartlardan ziyade şairin mizacıyla yakından ilgili olduğu muhakkaktır.

Şahsiyet bir bütün olduğuna göre, onun elinden çlkan her eser de onun izlerini bulmak mümkündür. Her sanatkârın bakış açısı farklıdır. Her sanatkâr varlığı, değişik tarzda ele alır, işler ve bir prizma misali eşyayı kendi menşurundan yansıtır. Mesela coşkun ve gür bir üslupla savaş ve dövüşleri anlatan aşağıdaki şiir Köroğlu'nun mizacının eseridir, denebilir.

Benden selam olsun Bolu beyine

Çıkıp şu dağlara yaslanmahdır

Ok gıcurtısından kalkan sesinden

Dağlar gümbür gümbür seslenmelidir.

Köroğlu - Halk Edebiyatına Giriş (Elçin, 1986:202)

Öte yandan karamsar ve kötümser bir sanatkâr ise en olumlu, en neşeli durumlarda bile eserlerine kasvet, karamsarlık ve kötümserlik bulaştırır. Sanatkârın mizacı ile sanat eseri arasında ilişki bulunmadığını ileri sürenler de şu görüşleri ifade etmektedirler: "Acaba bütün sanat eserleri gerçekten sanatçının kendi duygularının anlatımı mıdır? Sanatçı her zaman duygularını dile getirmeye mi çalışıyor?” sorularını da dikkate almak yerinde olur. Birçok sanatçının bir duygu ile işe başladığını ve

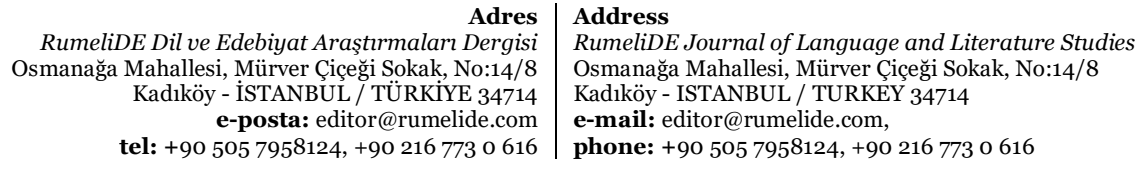


bunu ifadeye çalıştığını söyleyebiliriz. Bazı eserler böyle doğar; özellikle romantik devir sanatçıları için söylenebilir bir sözdür bu ve yine özellikle lirik şiir alanında genellikle doğru bir görüş sayılabilir (Moran, 1994: 100).

Romantik sanatçıların kişiliklerinin değişmeden, olduğu gibi eserlerine yansıdığı inancını da şüphe ile karşılamalıyız. Günümüzde bu konuda çok uyarmalar yapılmıştır. Unutmamalıyız ki bu tip sanat eserleri için, sadece bir kişiliğin dile getirilmesinden ibarettir denemez. Sanatçı dile getirdiklerini yazdığı türün geleneklerine göre yoğurur. Biçime sokulan ham madde değişime uğramış olabilir. Wellek ile Warren'in dediği gibi psikolojik bir olguyu da hesaba katmalıyı. Eser belki sanatçının gerçek kişiliğini değil, olmak istediği kişiyi yansıtmaktadır. Ya da belki "Yazarın arkasına gizlendiği bir 'maske' bir karşı-kişidir.” ya da yazarın kaçmak istediği bir yaşamın anlatımıdır (Rene Wellek and Austin Warren, 1949: 67).

Edebiyat ile sanat arasında var olan bu ilişkiden hareketle her sanatkârın eserinin bir köşesine kendisini veya düşüncelerini koyduğuna ilişkin varılan bakış açısı, sanatçının şahsi mizacı ile sanatı arasındaki ilişkiyi açıklamaktadır. Sanat eserinde sevilen, estetik haz duyulan nesnelere yüklenen anlamlar çoğunlukla mantıki değil şahsidir. Bunun için sanatçının mizacını sanat eserine yansıtması kaçınılmaz hale gelir. Sanatkâr bir sanat eseri meydana getirirken bir dereceye kadar, hayat ve tabiatı taklit edecektir. İşte bu taklidi yaparken, sanatkâr, mizacının etkisi altında kalmaktan kurtulamaz.

Bu noktada sanat ile şahsî mizaç arasındaki ilişkiyi açıklamak için birkaç örnek üzerinde duralım: Mevlana'ya gönderme yapılan aşağıdaki sözde baş olmanın, öğünmenin boş ve yararsız hatta istenmeyen sonuçlara davetiye çıaracağı; hatta örtük olarak huzur ve güvenliğin tevazuda olduğu ima edilmektedir.

\section{Baş olanlar öğünmesin ne gelirse başa gelir \\ Diz topră̆a yaslanır da baş düşerse taşa gelir (Mevlana)}

Necip Fazıl ise baş’a dini-hümanist bir anlam yüklemektedir. Nitekim toplumun sıkıntılarıyla zonk zonk zonklayan o başa dünyada rahat yoktur; huzur ancak secde anında söz konusudur. Necip Fazıl'ın huzuru, kulun Rabbine arada hiçbir engel olmadan, doğrudan içini döktüğü ve kulluğun hazzını duyduğu bir nokta olan secde anında bulması onun kulluk bilincini gözler önüne sermektedir:

Başım

Zonklayan başım benim, kan hokkası, cerahat

Ona yastıkta değil, secde yerinde rahat (Çile: 36).

Başım

Eklense de başıma dünyada kaç baş varsa;

Başım onlarm hepsi için secdeye varsa. (Çile: 60)

Ahmet Haşim ise aynı nesneye psikolojik bir bakış açısı ile yaklaşıyor ve baş'a mitolojik bir anlam yüklüyor: Bu baş habersizce gelip gövdesine oturmuştur. Kendisine ürküntü vermekte ve sürekli sıkıntı üretmektedir. İfrit gibi bir mitolojik varlık olan bu baş ona rahat yüzü göstermemektedir.

$\cdots$

Dişi, turnakları geçmiş etime

Gövdem üstünde duran ifritin

Bir küçük lahzâ-i arama fedâ

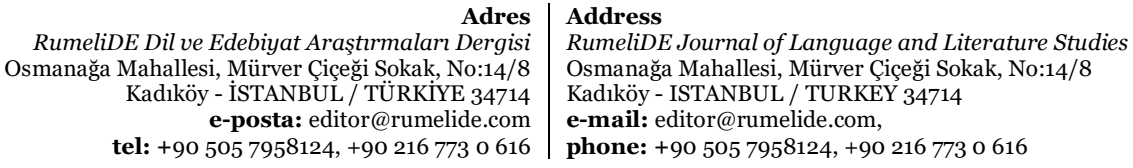


Bütün âlâyişi nâm u sıytin (Ahmet Haşim)

Bu örneklerde Mevlana'nın bilge kişiliği ile insanları doğru yola iletme, Necip Fazıl'ın inanmış samimi bir dindar edasıyla yüce Yaratıcı karşısındaki tevazu gösterme, Ahmet Haşim’in kendi varlığı üzerindeki dramatik ruh hallerine şahit oluyoruz. Bu örneklerden hareketle sanatkârların kendi mizaçlarının etkisinde kaldıkları sonucunu çıarmak mümkündür. Yukarıdaki örneklerde her bir sanatçı, aynı görüngüyü betimlemek için kendi his durumundan, kendi penceresinden görmeye ve göstermeye çalışmıştır.

Sanatçı kendini rahatsız eden, zorlayan, dürten birtakım duyguları dile getirmek ihtiyacı içindedir. Bu duygulara bir biçim verip sanat eseri halinde ifade edince öfkelenen bir insanın bağırıp çağırınca rahatlayışına benzer bir psikolojik dengeye ulaşır.

\section{Sonuç}

$\mathrm{Bu}$ çalışmada sanat ile mizaç arasındaki ilişki bağlamında Türk edebiyatında mizaç farklılaşması üzerinde durulmuştur. Edebî eser ile okur, tarih ve toplum arasındaki bağ, sanat eseri ile sanatkârın mizacı arasında da bulunmaktadır. Elde edilen bulgular ışı̆̆ında, her sanatkârın farklı bakış açısına sahip olduğu, eserlerini üretirken her birinin kendi mizacının etkisinde kaldığı söylenebilir.

1. Araştırmamızda incelediğimiz Ahmet Haşim'ın kendi varlığı ile ilgili olarak dramatik bir algıya sahip oluşunu Başım adlı şiirinde kendi başını 'Dişi, turnakları geçmiş etime / Gövdem üstünde duran ifritin' dizeleri ile betimlemektedir. Haşim, ölünceye kadar bu zeki baştan hep ürkmüştür. Kaplan’ın onun mizacıyla ilgili olarak 'Şahsî psikolojisi de Hâşim'de bu duyguyu beslemiş olmalıdır.' şeklindeki değerlendirmeleri Başım adlı şiiri ile Ahmet Haşim’in mizacı arasındaki ilişkinin varlığını desteklemektedir.

2. Behçet Necatigil, Dışarda başlıklı şiirinde zenginler ve fakirler arasındaki tezadı çarpıcı bir tarzda dile getirmektedir. Kaplan'a göre Dışarda başlıklı şiirde sokak veya vitrinlerin şairde bu duyguları uyandırmasının sebebi, fakirliğinden utanma ve ezilme hissidir. Şair, bulunduğu ortamdan rahatsızdır; evine dönmek ister. Evleri dış dünyanın baskısı altında bunalan sıradan insanın sığınabileceği tek mekân olarak düşünür. Bunun sebebinin şairin şiirinde sözünü ettiği bu duyguyu bizzat yaşıyor olmasıyla açıklanabilir. Necatigil'e göre 'Asıl olan duygudur, kesin bir duyarlıktır. Sonra da bunu elden geldiğince ustalıklı biçimlendirmedir.' Necatigil bu şiirde dile getirdiği duyguyu derinden hissetmesinin altında kendi mizaç ve yaşantılarının etkisi olduğu söylenebilir.

Kaplan'ın 'Necatigil şïrlerinin konularını çoğunlukla kendinden ve çevresinden alır.' şeklindeki ifadeleri sanatkârın mizacıyla eserleri arasında bir ilişkinin varlığını destekliyor. Nitekim Kapalçarşı'da evlilik, mutlu aile düşleri ve yaşama temaları Çevre'de yalnız insanın dramı ve aile kurma özlemi gibi temaların işlenmiş olmasıyla Dışarda şiiri arasında da tematik bir yakınlığın bulunması kendi yaşantı ve mizacının etkisini gösterir.

3. Necip Fazıl’ın "Bu Yağmur" adlı şiirinde dış dünyadaki basit bir nesneden hareketle ferdi bunalımlarını anlatmaktadır. Onun ıstırabı daha ziyade ferdi ve metafizik bir mahiyetedir. Necip Fazl'a hayatı boş, karanlık ve karışık gösteren ruhi sıkıntılar dıştan değil, içten kaynaklanmaktadır. Şiirinde dış âlem, kendi iç âleminin objektif karşılı̆̆ını oluşturur. Bütün eserlerinde değilse bile "Bu Yağmur", Kaldırımlar gibi şiirlerinde onun ferdi bunalım ve hafakanlarının eserlerine yansıdığı söylenebilir.

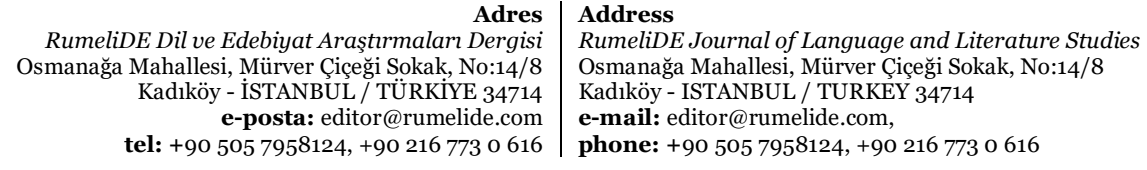


Denilebilir ki mizaç, sanatkârı mukallit olmaktan kurtarır. Mizaç, sanatkârın özgün kişiliğinin sanat eserine yansımasının en önemli göstergesidir. Sanat, duyguların ifadesidir, dolayısıyla onu var eden kişiyi yansıtır. Eserleri daha iyi anlayabilmek için, sanatçının hayatını, zevklerini, psikolojisini tanımak gerekir.

Öte yandan sanatkâr içinde bulunduğu toplum ve çevrenin etkisi altındadır. Ancak sanat, esas olarak şahsîdir. Bir sanat eseri, sanatkârın dünya görüşünün, değer yargılarının, hayata hangi pencereden ve nasıl baktığının izlerini taşır, bir başka ifade ile sanatkârın mührünü taşır. Bu yüzden, bir sanatkâr eserini meydana getirirken bir fotoğrafçı sadakatiyle hareket etmekten kurtulup kendi mizacını eserine yansıtabildiği ölçüde başarılı olabilir. Sanatkârların farklı mizaçları olmasaydı, sanat kısır bir döngü içerisinde boğulup giderdi denilebilir. Mizaçtaki farklılıktır ki aynı konuyu işleyen sanatkârların değişik renk, ses, tat ve çeşnide eserler vücuda getirmesine yol açmış; bu sayede insanlık renkli ve zengin bir kültür birikimi elde edebilmiştir.

Sanat, duyguların ifadesidir ve onu üreten yazarın kişiliğini yansıtır. Kişinin mizacını etkileyen sanat akımı, yaşadığı coğrafya ve içinde bulunduğu hayat şartları gibi olası etkenler yanında sanatçının hayatını, zevklerini, psikolojisini tanımak gerekir. Sanat eserlerini anlayabilmenin ve estetik zevk edinebilmenin yolunun, sanatçının mizaç ve psikolojisini tanıma ile yakından ilişkili olduğu söylenebilir.

Sanatkârın hayatında yer alan olaylar, içinde yaşadığı şartlar, aile ortamı, okuduğu kitaplar, başında geçen olaylar eserlerine siner. Okur esere sinen bu bilgiler aracılığıyla sanatkârın psikolojik durumunu belirler, bu yolla eser üzerinde sağlam yorumlar ve çıkarımlar yapar.

\section{Kaynakça}

Ahmet Haşim (1927). "Başım”. Hayat Mecmuası 20: 5.

Atlı, 2012: 264 Atlı, F. (2012). Edebi Metin ve Yaratıcılı̆̆ın Kaynağına Ulaşan Yol: Psikanalitik Edebiyat Eleștirisi. Turkish Studies- International Periodical For The Languages, Literature and History of Turkish or Turkic Volume 7/3, Summer 2012, p. 257-273, Ankara-Turkey

Avcu Deniz G., (2019), Yeni Türk Edebiyatında Portre Türünün Gelişimi, Yüksek Lisans Tezi, Tez Danışmanı, Fikret Turan, İstanbul. http://nek.istanbul.edu.tr:4444/ekos/TEZ/ETooo582.pdf

Calp, M. (2017), Edebiyat Bilgi ve Kuramları l, Nobel, Ankara.

Cloninger C. R, Svrakic D. M (200o), Personality disorders. In B. J. Sadock and V. A. Sadock (Eds.), Comprehensive Textbook of Psychiatry, 7th. ed., Baltimore: Williams \&Williams.

Croce, Benedetto (1909), Aesthetic as Scıence Of Expression and General Linguıstzc Translated From The Italıan of Benedetto Croce by Douglas Ainslie B.A. (Oxon.) 1909 http://publiclibrary.uk/pdfs/1/429.pdf (Erişim Tarihi: 20.02.2020):

Çakmaker, S., (2014), Necip Fazıl Kısakürek’in şïrlerinde sosyal eleştiri bağlamında "ev" ve "ağaç" meteforu, Yeni Türk Edebiyatı Araştırmaları.

Çetişli, İ., (2004) Şïr Tahlillerine Giriş I, Akçă̆, Ankara.

Elçin, Ş. (1986) Halk Edebiyatına Giriş, Kültür ve Turizm Bakanlığı Yayınları, Kültür Eserleri Dizisi: 52. Ankara.

Erol, K. (2018), Necip Fazıl'ın Şiirinde Toplumsal ve Kültürel Dejenerasyon, Adam Akademi, 8/1 2018:57-80

Gariper, C. (2005). Necip Fazıl'ın Çan Sesi Şiirine Hermeneutik Bir Yaklaşım, İlmî Araştırmalar, 19, 6778.

Hisar, Abdülhak Şinasi, (1963), Ahmed Haşim Şïri ve Hayatı, İstanbul.

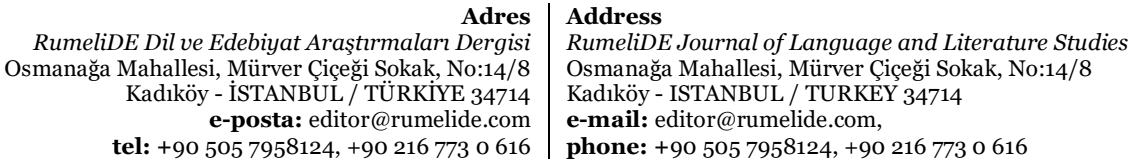


http://earsiv.sehir.edu.tr:8080/xmlui/bitstream/handle/11498/10588/001507632006.pdf?sequence $=1$ (Erişim Tarihi: 26.02.2020)

Kaplan, M., (1978). Şiï Tahlilleri 1 Dergâh Yayınları, 6. Baskı, İstanbul.

Karasar, N. (2016), Bilimsel Araştırma Yöntemi. Ankara: Nobel Yayın Dağıtım.

Kısakürek, Necip F., (1978). Çile, Büyük Doğu Yayınları, Çağaloğlu-İstanbul.

Kolcu, A, İ. (2008), Tanpınarı’n şïrinin epistemolojik temeller ve Tanpınarı’n şïr estetiği, Salkım Söğüt Yayınevi, Erzurum.

Moran, B., (1994), Edebiyat Kuramları ve Eleştiri, Cem, 9. Baskı, Beyoğlu İstanbul.

Necatigil, B., (1999) Düzyazılar II: Yapı Kredi, İstanbul.

Nergiz, G. (2017). Susanna Tamaro'nun Tobıa ve Melek Kitabındaki Kahramanların Carl Gustav Jung'ın Psikanalitik Bakış Açısıyla İncelenmesi. Uluslararası Çocuk Edebiyatı ve Eğitim Araştırmaları Dergisi (ÇEDAR), 1 (1), 51-63. Retrieved from https://dergipark.org.tr/tr/pub/chedar/issue/36974/410648)

Okay Orhan, (2005) Poetika Dersleri, Hece, Ankara.

Özpalabıyıklar, S., (2015), Behçet Necatigil Eski Sokak, 5. Baskı Yapı Kredi.

Selçuk, Z. ve E. D. Yılmaz. (2017). Rehber Benim. Ankara: Elma.

Şahin, V. (2006). "Sevgilerde" Şiir Üzerine Bir Tahlil Denemesi". Firat Üniversitesi Sosyal Bilimler Dergisi, S. 16/2, s. 73-82.

Şimşek, Tacettin, (2018), Behçet Necatigil’in Şiirlerinde ‘Şair Özne’nin Yazgısı, Erzincan Üniversitesi Sosyal Bilimler Enstitüsü Dergisi (ERZSOSDE) XI-II: 1-13

Şişmanoğlu, Ş. (2003). Behçet Necatigil ve Şiirin Ev Hali. (Yüksek Lisans Tezi). Bilkent Üniversitesi. Ekonomi ve Sosyal Bilimler Enstitüsü: Ankara.

Tolstoy, Leo, (1904) What is Art? Orijinal el yazmalarından çeviren ve önsöz: Aylmer Maude, Grant Richards, Londra.

Tunç, G., (2019), "Behçet Necatigil Şiirini Üç Gösterge İle Okumak: Parantez, Düşünce Çizgisi ve Kare”, Türkiyat Araştırmaları Enstitüsü Dergisi - TAED-65, Mayıs - Erzurum.

Wellek, Rene (1969), Concepts of Criticism Fifth Printing, October, New York.

Wellek Rene and Warren Austin (1949), Theory of Literature, New York: Harcourt, Brace \& Co.

Yaşar, M., (2018), "Kişisel Mizacın Resim Sanatına Yansıması”, II. Uluslararası Sanat ve Estetik Sempozyumu Tam Metin Kitabı, Elazığ.

Yıldırım, A. \& Şimşek, H. (2013). Sosyal Bilimlerde Nitel Araştırma Yöntemleri, (9. Baskı). Ankara: Seçkin.

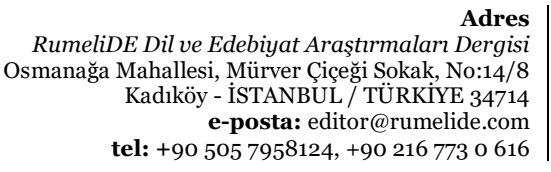

dres

RumeliDE Journal of Language and Literature Studies

Osmanağa Mahallesi, Mürver Çiçeği Sokak, No:14/8

Kadıköy - ISTANBUL / TURKEY 34714

e-mail: editor@rumelide.com,

phone: +90 5057958124 , +90 2167730616 